\title{
Marginal gains or diminishing returns? Penal bifurcation, policy change and the administration of prisoner release in England and Wales
}

\author{
Thomas Guiney
}

\begin{abstract}
Prisoner release has emerged as a key site of penal policy contestation in England and Wales. A series of crises have undermined public confidence in the parole system and reopened longstanding debates over the confused normative basis of prisoner release policy and practice. This paper attempts to locate current concerns within an ideational interpretation of penal policy change. It will argue that prisoner release has been fundamentally re-shaped by a bifurcated penal strategy which emerged as one possible response to the unique challenges of late-modern crime-control. Over time this strategy has provided an enduring guide to collective action and a political template for successive penal reform programmes. However, there are signs that we may now be reaching the conceptual limits of this strategy. While the logic(s) of bifurcation will continue to yield marginal political gains in the short-term, this paper concludes that the longterm prognosis is one of diminishing returns with significant implications for the legitimacy, effectiveness and administrative coherence of prisoner release in this jurisdiction.
\end{abstract}

Keywords: parole, early release, penal policy, bifurcation, sentencing, law and order

\section{Introduction}

Prisoner release has emerged as a key site of penal policy contestation in England and Wales. What was once a secretive and paternalistic procedure, to be administered by a small coterie of experts in the shadow of the prison gates, has become a matter of intense public interest (Guiney 2018). As the Home Office noted more than sixty years ago, 'it is easy to imprison a man; the 
difficult thing is to release him' (1959: 19), and while it is true that prison release has always been a complex site of penal policy-making, the current administrative architecture has come under unprecedented strain as it struggles to: (a) keep pace with the increasing scale and complexity of the prison population; (b) reconcile the legitimate expectations of public law, an increasingly influential victims' movement and the many prisoners who interact with the system on a day-to-day basis (Padfield 2007). These pressures ripple out across the penal system, but arguably find their most public expression in the growing frequency of so-called 'hard cases'-such as the release of John Worboys--where conflicting actuarial, legal and moral principles achieve crossover media attention (see Padfield this volume).

The failure to resolve these fundamental tensions has eroded public trust in the parole system and reinvigorated longstanding debates surrounding the confused normative basis of prisoner release in this country (Shute 2003). And yet, despite these pressures, it is noteworthy that the official response within government has largely eschewed novel answers to such questions. Preferring instead (amongst other things) to double-down within a policy framework Anthony Bottoms has described as a bifurcated, or twin-track, penal strategy which distinguishes between the treatment of dangerous violent and sexual offenders, and those 'minor' criminals, typically found guilty of volume property offences (1977: 87). ${ }^{1}$ To take but one recent example, in February 2019, the Ministry of Justice (MOJ) announced 'sweeping changes' to the parole system as it applies to the most serious offenders (MOJ 2019a), whilst in parallel introducing measures intended to promote greater use of early release for the majority of determinate sentence prisoners (MOJ 2019b). Setting out his commitment to a 'smarter' justice system the then Justice Secretary, fell back upon a familiar bifurcated narrative, I do not want to reverse the tougher sentencing approach for serious offences. But equally, we should be extremely cautious about continuing to increase sentences as a routine response to concerns over crime' (MOJ 2019a). 
In this paper I reflect upon the continuing relevance of Anthony Bottoms' theoretical work on penal bifurcation $(1977 ; 1980)$ and how these insights, initially advanced with reference to developments in 'front end' sentencing policy, can be applied to the 'back end' of the criminal justice system and contemporary prisoner release arrangements. Presented with a restrictive policy environment where penal policy-makers have struggled to reconcile significant reductions in public expenditure and a tightly delineated cross-party consensus on crime I question whether a bifurcated penal strategy will continue to deliver the marginal gains politicians are seeking or is now subject to the law of diminishing returns. My answer to this question will proceed in three parts: First, I discuss the penological assumptions that underpin a bifurcated penal strategy and why these ideas have found such pronounced expression in prison release policy and practice. Second, I review the current release framework in England and Wales and reflect upon the administrative implications of a system which now operates as both a bridge and a barrier between prison and the community. Third, I attend to the possible futures of prison release. Drawing upon insights from the political science literature on policy change and the role of ideas in politics (Beland and Cox 2010; Hall 1989) I argue that the repeated extension and adaptation of a two-track approach has created several fault lines within contemporary penal policy with significant implications for the legitimacy, effectiveness and administrative coherence of the current prisoner release framework.

\section{Penal bifurcation and prisoner release}

Since the trend was first described by Anthony Bottoms in 1977, a bifurcated penal strategy has proved extremely influential in government thinking. It has been exported globally (Seeds 2017) and now finds expression throughout the entire criminal justice system: In the rhetoric of law and order politics (Downes and Morgan 2012), sentencing guidelines (Ashworth 2010: 293) and the organisation of the probation service (Burke and Collett 2016). However, it is in relation to prison release where some of the most pronounced effects can be observed (Padfield et al 2010: 
104). To some extent, the operation of prison release in England and Wales has always been administratively bifurcated to the extent that it pivots upon a shifting demarcation between the discretionary parole system and automatic release arrangements (Guiney 2018: 55). Over time these policy levers have served a variety of purposes, but it is the way they have been put to work within contemporary penal policy that is of interest here. This general picture suggests that prisoners serving indeterminate or extended determinate sentences for serious violent and sexual offences are subject to an increasingly prohibitive system of discretionary decision-making, couched in the language of risk, dangerousness and public protection (Pratt 1995). In contrast, those 'ordinary' prisoners serving determinate prison sentences now qualify for a series of automatic release pathways designed to accelerate their progress through the prison estate.

What happens at the 'front end' of the criminal justice system often finds administrative expression in prisoner release decision-making, and the intellectual origins of a two-track approach can be traced back to declining faith in the 'rehabilitative ideal' as an expression of official policy. This policy window created the space for new ideas to break on to the political agenda and it was in this context that Bottoms observed the development of two ostensibly contradictory trends within British penal policy: a largely overlooked growth in the use of fines and other diversionary practices and the 'renaissance of dangerousness' as a central concern within criminology (1977; 1980). For contemporaries, such as Mathews (1979), these developments were emblematic of the fiscal crisis of the modern state which forced penal policymakers to explore less costly forms of social control than total institutionalization. However, Bottoms alighted upon a Durkheimian reading of the shifting contours of crime control in the late-1970s. While advanced societies, defined by complexity and growing individualism, are likely to express declining interest in technical rule breaches, the gradual weakening of traditional social bonds may in time generate counter movements and support for measures which reassert a 'conscience collective' during periods of profound social change (Bottoms 1977: 90). 
The collapse of the post-war settlement (Kerr 2001) was one such occasion, and in the criminal justice sphere these broader social insecurities began to manifest in penal policies that sought to promote the traditional moral content of the criminal law--particularly those crimes we all claim to abhor--with a more regulatory attitude reserved for volume property offences. This analysis proved remarkably prophetic. Several years later the Home Secretary, Leon Brittan, would use his keynote address to the 1983 Conservative Party Conference to deliver what is now considered the classic statement of a bifurcated prisoner release position:

\begin{abstract}
What I intend... is that no one sentenced to more than five years' imprisonment for an offence of violence to the person shall be released on parole except where release under supervision for just a few months before the end of the sentence is likely to reduce the long-term risk to the public... It is also right that those who pose no such risk either do not go there [prison] in the first place or are released when they have suffered the first short, sharp shock of custody.
\end{abstract}

In this way a twin-track approach allows government to 'get tough and soft simultaneously' (Pitts 1988: 29). To project an image of enhanced social insurance, while in fact reducing its coverage overall as more immediate crime risks are transferred from the state to its citizens and the markets (Pratt 1995: 17). As Garland (1996) has argued, high crime rates have become a 'normal social fact' in many advanced liberal democracies. Criminal justice agencies (such as the Parole Board) have struggled to manage caseloads of increasing volume and complexity, and over time this has eroded one of the foundational myths of modern societies; that the sovereign state can deliver effective crime control within its territorial boundaries (Garland 1996: 448). This predicament has presented an enduring political challenge to penal policy-makers who quickly recognised the need to "withdraw or at least qualify their claim to the primary and effective providers of security and crime control' but foresaw just as clearly, 'that the political costs of such a move are likely to be disastrous' (Garland 1996: 449). Confronted by this insoluble political dilemma penal policy-makers have embraced a dualistic crime control response which oscillates between an expressive 'criminology of the other' and a series of 
pragmatic adaptations which have informed a more administratively focused 'criminology of everyday life' (Garland 1995: 448).

Viewed in these terms, the great achievement of a twin-track approach was not only to deliver a series of policy adaptations to the predicaments of late-modern crime control, but to (re)define public discourse on crime more generally (Seeds 2016: 600). Penal bifurcation militates against a liberal account of crime as falling on a continuum of harm, replacing it instead with a reductive, and somewhat binary image of criminal behaviour which allows for 'different accounts of human nature and human action to be accepted for different types of offender in order to justify different legal responses' (Brown 1996: 18). While 'ordinary offenders' assumed to be of rational mind can continue to be managed through neoclassical crime control techniques, such as deterrence and situational crime control, the treatment of dangerous 'others' becomes increasingly exclusionary in its orientation, with a strong focus upon public protection, incapacitation and risk-management (Brown and Pratt 2000: 35). This is both the great strength and biggest weakness of a bifurcated penal strategy. As Kemshall has argued, the maintenance of a two-track system relies upon a series of highly questionable assumptions which are extremely difficult to administer in practice,

Bifurcation presumes easily distinguishable thresholds between risk categories, accurate risk assessment within prisons and classification of prisoners, and fail-safe parole decisions, and that risk remains static upon release. These are unsound assumptions and create systematic flaws in the operation of a bifurcated approach. (Kemshall 2013: 271)

Above all else, the use of criminal law to separate out 'dangerous' and 'ordinary' offenders has driven ongoing reform at the top-end of the sentencing framework with significant implications for the scale, scope and reach of the discretionary parole system. As originally conceived, parole was justified on the basis of a 'recognisable peak' in an individual's rehabilitation where the interests of the community were better served by their careful reintegration rather than their 
continued incarceration (Guiney 2018; Shute 2003). The rehabilitative ethos has not disappeared entirely from view (see Robinson 2008), but with the emergence of a more contested discourse on law and order this inclusionary / exclusionary calculus has now been almost completely inverted for those who must satisfy the Parole Board that they are no longer represent a risk to the public. Dangerousness has, and always will be, an ambiguous concept upon which a range of social insecurities are projected. However, in recent decades it has become synonymous with indeterminacy (see for example Annison 2015) and forms of extended sentencing where questions of individual liberty come to rest upon a plethora of predictive penal technologies blending aspects of the 'new penology' (Feeley and Simon 1992) and older therapeutic accounts of individual pathology.

This analysis makes clear that prisoner release should not be viewed as tangentially connected to a bifurcated penal strategy, but constitutive of it. As I have argued elsewhere (Guiney 2018 p.6), prison release has always been bound up with societal justifications for punishment, the limits placed upon the executive within our liberal democratic system and the administrative challenge of governing a large captive populations where the hopes and expectations of prisoners do not always align with the interests of prison authorities or the community at large. A twin-track approach does not provide a definitive solution to these problems but, it does offer a template for collective action which has proved remarkably attractive to penal policy-makers at an administrative, political and ideological level (Hall 1989: 369). Politically, the discretionary parole system offers a natural focal point for politicians seeking to articulate penal policies which exhibit toughness with regards to serious violent and sexual offending. From the point of view of the current 'resources crisis', the basic demarcation between the discretionary and automatic release systems offers a powerful tool of demand management and a pragmatic response to high administrative case-loads which cannot all be dealt with by way of a resource intensive, discretionary system (Cavadino et al 2013: 27). While it has been commonplace to separate out prisoner release from sentencing practice and the 
discretionary parole system from automatic release arrangements, these relationships must be viewed as symbiotic. To a significant extent, the new politics of parole is founded upon, and made possible within, a broader automatic release ecosystem.

\section{Contemporary prisoner release in England and Wales}

For these reasons a bifurcated penal strategy has provided an enduring guide to penal reform, finding expression in political rhetoric, policy directions and primary legislation. In this section I move on to survey the contemporary landscape of prisoner release in England and Wales. Official statistics reveal that on the 31 March 2019, the sentenced prison population stood at 72,860 (excluding those held on remand). Of this total; 55,587 were determinate sentence prisoners $(76 \%), 9,441$ were subject to some form of indeterminate detention (13\%) and a further 7,179 prisoners were held in custody following their recall to prison (10\%) (MOJ 2019c). We will see that under existing release arrangements these distinct prisoner cohorts can expect a very different carceral experience as they progress through the prison estate.

The current legal framework for the release of prisoners in England and Wales flows from the Criminal Justice Act 2003. For the majority of prisoners serving determinate sentences, release is automatic at the mid-way point. Initially, prisoners serving short custodial sentences of 12 months, or less, were released unconditionally with a more resource intensive system of supervised release on licence reserved for those serving longer determinate sentences. However, following the introduction of the coalition government's Transforming Rehabilitation reform programme and the partial-privatisation of the probation service (Burke and Collett 2016), there has been a marked shift towards greater conditionality in post-release supervision. ${ }^{2}$ Since the activation of the Offender Rehabilitation Act 2015 in February 2015 all prisoners sentenced to custody for more than one day and less than two years are released under the supervision of a probation officer for a period of 12 months during which time they may be recalled to prison if they breach their licence conditions. 
In addition to statutory release arrangements, many determinate sentence prisoners qualify for early release under the Home Detention Curfew scheme (HDC). After a period of significant retrenchment, the MOJ published new guidance in March 2019 which seeks to reposition electronic tagging as a 'normal' part of sentence progression (MOJ 2019b). Prisoners serving determinate sentences of at least 12 weeks, but less than four years, may be released on electronic tag for a maximum period of 135 days, once they have served the requisite custodial period of their sentence. Laudable aims perhaps, but in practice the scheme continues to exclude many categories of prisoner including; 'sex offenders required to register', extended sentence prisoners, and those who have previously breached the terms of their licence (MOJ 2019b).

The discretionary parole system operates rather differently. Under current arrangements the Parole Board of England and Wales is responsible for the release of prisoner's subject to: (i) indeterminate prison sentences (see Padfield 2010); (ii) extended determinate prison sentences; (iii) determinate sentence recall proceedings. In addition, the Parole Board retains several ancillary functions, including the provision of advice to the Secretary of State on progression from closed to open conditions for some indeterminate prisoners. The Board is comprised of 238 non-executive members and is currently supported by a secretariat of 128 officials, with an operating budget of approximately £18 million per annum (Parole Board 2018: 41). In 2017/18, the Board completed 12,625 paper hearings and conducted 8,137 oral hearings in accordance with the legal principles set down in Osborne (Osborne, Booth and Reilly v. The Parole Board of England and Wales, [2013]). Excepting the 62 prisoners serving whole life sentences at the time of writing (MOJ 2019c), it is the responsibility of the sentencing judge to set out the minimum term, or tariff that must be served before an application for release can be considered by the Parole Board. In theory, this should not be treated as a re-sentencing exercise. Once the tariff, or punitive portion of an indeterminate sentence has been served, continued incarceration can only be justified in law where the Parole Board determines that the individual still poses a significant risk to the public which cannot be managed adequately within the community. 
Since the Criminal Justice Act 2003 the Parole Board also plays a more defined role in the management of 'dangerous offenders' where a violent or sexual offence has been committed, as 'specified' under Schedule 15 of the Act, and 'the court is of the opinion that there is a significant risk to members of the public...'. Initially this centred upon the cases of prisoners serving an Indeterminate Sentence for Public Protection (IPP) and a lower tier sanction known as the Extended Sentence for Public Protection (EPP). However, these powers were subsequently abolished (although not retrospectively) by the Legal Aid Sentencing and Punishment of Offenders Act (LASPO) 2012 and replaced by a consolidated Extended Determinate Sentence (EDS) to be activated in cases where a life sentence would not be proportionate (see Annison 2015). On 31 March 2019 there were 5,262 prisoners serving an EDS sentence in England and Wales (MOJ 2019c), and s.125 of the LASPO, makes clear that the Parole Board must not provide a direction for their release unless 'it is satisfied that it is no longer necessary for the protection of the public that [the prisoners] should be confined'.

It can be difficult to disaggregate the impact of prisoner release from sentencing powers and criminal justice practices more generally. However, the available evidence does suggest that the current release framework has contributed to both the growth and reconfiguration of the prison population with significant implications for everyday prison life and the demands placed upon the prison system:

- Offence category: In the past two decades the offence composition of the prison population has changed dramatically (see Table 1). In 2015 the MOJ changed the way it categorises criminal offences in order to bring its reporting systems into line with the Office for National Statistics (ONS) and this can make historical comparison difficult. However, for the period 2002-2014, where we do have consistent data, official statistics reveal a marked increase in the proportion of prisoners serving immediate custodial sentences for sexual offences and violence against the person. In the case of prisoners 
held in custody for sexual offences the growth has been particularly pronounced, rising from 5,294 prisoners in June 2002, to 11,192 in June 2014, an increase of $111 \%$ in just 12 years. In contrast, the number of prisoners under sentence for 'theft and handling', or 'burglary' fell by $8 \%$ and $22 \%$ respectively during the same period.

- $\quad$ Sentence length: Reform at the top end of the sentencing framework has significantly increased the number of long-stay prisoners within the custodial estate. The result is an increasingly static and ageing prison population. Prisoners serving indeterminate sentences more than doubled between 2005 and 2018, although it should be noted that this headline figure has started to decline, albeit slowly, since the abolition of the IPP sentence (Table 2). Of particular note is the growing number of prisoners serving long determinate sentences of four years or more (including the extended determinate sentence). This cohort of prisoners has increased steadily from almost 26,500 prisoners in 2005 , to approximately 34,000 in 2018 , representing an increase of $29 \%$ in little more than a decade. In contrast, the number of prisoners serving sentences of 1-year or less, or 12- months to less than 4-years, has fallen as a proportion of the overall prison population, although significant differences do remain with regards to race and gender (MOJ 2019c).

- $\quad$ Time spent: A pronounced bifurcated effect can be observed with regards to the amount of time, on average, prisoners spend in custodial settings. The most recent figures reveal that the mean time spent in prison by those sentenced to determinate prison sentences of 6 months or under, fell from 3.4 months in 2005, to 3.1 months in 2018, a fall of almost $10 \%$ in thirteen years (see Table 3 ). In contrast, the average time served by prisoners serving mandatory life sentences increased from 168 months in 2005 to 204 months in 2018 , a rise of $21 \%$ in thirteen years. The time spent by 'other lifers', 
including the large number of IPP prisoners now held post-tariff, was even more apparent; rising by $183 \%$ from an average of 72 months in 2005 to 204 months in 2018 .

\section{Insert Table 1, Table 2, Table 3 (grouped)}

\section{Discussion: The possible futures of late-stage penal bifurcation}

In this paper I have discussed the continuing importance of Anthony Bottoms' theoretical work on penal bifurcation $(1977 ; 1980)$ and how these insights can help us to make sense of recent developments in prisoner release policy and practice. I have argued that the basic organisation of prison release in England and Wales--a system which pivots upon the demarcation between discretionary parole and automatic release arrangements--has proved particularly well suited to the development of a two-track approach and is now constitutive of a policy framework which seeks to differentiate between the treatment of 'dangerous' and 'ordinary' offenders. Over time, penal bifurcation has provided an enduring guide to collective action and the legacy of these policy choices can be seen in the transformation of the prison population according to offence categorisation, sentence length and time-served (for more on the process of 'violence realignment' see Seeds 2016: 600). But what off the future? In the space remaining, I want to situate these debates within an ideational account of penal policy change (Beland and Cox 2010; Hall 1989). I argue that the repeated extension, adaptation and reformulation of a bifurcated position over several decades has undermined the delicate equilibrium that underpins a twintrack approach, resulting in increasingly unstable policy configurations I characterise here as late-stage penal bifurcation.

The evolution of prisoner release as a public policy concern offers a powerful reminder that policy-makers are not simply the product of material interests or institutional structures, but active participants in the creation of new political trajectories. To a significant extent our politics is both 'path breaking' as well as 'path dependent' and greater sensitivity to the reflexive position 
of policy actors within these structures can provide a powerful corrective to 'static', or overly determined accounts of the contemporary world. As Heclo observed, policy-makers "puzzle" as well as "power" (1974: 305), and it is through this dynamic process of social learning that individuals make sense of the world around them and calibrate their responses to new and emerging policy problems. In this respect, ideas not only underpin individual belief systems but provide the currency through which political dialogue and collective decision-making is made possible. Ideas 'matter' (Beland and Cox 2010: 17) and these ideational pathways can be observed at three distinct levels of practice: as 'policy solutions' to current concerns, in the active creation of new 'problem definitions' and the articulation of 'public philosophies' which offer a general orientation towards questions of government, society and the markets (Mehta 2010: 25).

These insights provide the theoretical scaffolding for thinking about the recent history of prison release. When viewed in ideational terms penal bifurcation can be understood as an active political strategy which seeks both to (re)define crime problems and promulgate policy solutions which are consistent with broader shifts in the political economy of crime. These ideas were by no means sui generis. A twin-track approach re-purposed existing practices and presented a way of thinking about crime that integrated policy, political and administrative innovations within a framework that could be implemented with only limited institutional resistance (see Shute 2003:403). The key point being that once accepted, these policy prescriptions began to coalesce into an institutionally recognisable policy tradition as alternative reform options were discounted and additional resources were committed to the delivery of a twin-track system (see Beckett et al 2018). Initially at least the more punitive aspects of this strategy were tempered by the traditions of British penal pragmatism (Windlesham 2001). However, as these ideas began to interact with an increasingly performative penal populism (Pratt 2007), the two-tracks of a bifurcated approach have come under increasing strain.

Put another way, penal bifurcation has demonstrated remarkable plasticity as a tool of penal policy, but like all ideas there are limits to its application. In practice, the difficulty of 
administering a two-track system (Kemshall 2013), coupled with the repeated extension, adaptation and reformulation of bifurcated logic(s) to new policy problems, has contributed to the emergence of three major fault-lines within contemporary prison release policy and practice: First, this process has placed increasing strain upon the Parole Board of England and Wales. As we have seen, the growing use of indeterminate detention and extended determinate sentences has the practical effect of shifting the locus of penal decision-making away from the sentencing judge, towards the Parole Board whose aptitude (Shute 2004) and legal standing (Padfield 2016) to make such decisions remains deeply problematic. In 2008, the Court of Appeal held that the Parole Board was insufficiently independent from the Secretary of State for Justice to discharge its responsibilities in accordance with the rule of law ( $\mathrm{R} v$ Brooke, [2018]) and the failure to resolve these questions resurfaced once again in the political fallout from the Worboys case ( $\mathrm{R}$ DSD \& Anor v The Parole Board of England and Wales, [2018]). The recent Ministry Justice 'review of the law, policy and procedure relating to Parole Board decisions' has seen incremental improvements to the transparency of Parole Board decision-making (MOJ 2018). Although, it remains to be seen whether the 'Tailored Review' of the parole system, announced by the Justice Secretary in early 2019, will entertain more ambitious options for the reconstitution of the Parole Board as an independent legal tribunal, as many have advocated (Padfield 2016).

Second, the 'toughening up' of a bifurcated penal response presents serious challenges to prisoners, penal administrators and the broader constellation of community services that work with individuals upon their release. In an era defined by risk-management and public protection it is perhaps understandable that the Parole Board has tended to measure its success against the small number of parolees that go on to commit a serious further offence (Parole Board 2018). However, this narrow and rather managerial focus has arguably prevented a more searching dialogue with regards to the administrative cost of maintaining these headline figures. As Hood and Shute noted at the turn of the century, the Parole Board has an altogether mixed track-record when it comes to distinguishing between 'false positives'--those prisoners who receive a 
favourable release decision but will go on to reoffend during their licence period--and a potentially far larger category of 'false negative' prisoners who are denied parole but would not have engaged in serious offending upon their release (see Shute 2004). The decision to prioritise the former over the later has seen a gradual hardening of the pathways to release. This has contributed to the growing use of prison as a place of containment and undermined efforts to build a stronger strategic focus on the community infrastructure needed to support the desistance process in the long-term. As a result many prisoners held post-tariff are unable to access the rehabilitative programmes they require to demonstrate a reduction in risk and progression from 'dangerous' to 'ordinary' offender (Kemshall 2013).

Third, it is increasingly apparent that late-stage penal bifurcation produces a number of political feedback-loops which ratchet up the pressure upon politicians in the short, medium and long-term. On the one-hand, the "hiving off" of dangerous offenders into a distinct legal category has amplified public anxieties about crime, delivered a near constant supply of 'folk devils' for those seeking to fuel moral panics about crime and emboldened those calling for greater protection from the State (see The Telegraph 19 May 2019). On the other, the increasing reliance upon administrative mechanisms to maintain a bifurcated system has, over time, become a lightning rod for populist movements which (rightly or wrongly) draw attention to issues of transparency and executive interference, and demands for greater 'truth in sentencing' (Guiney 2018: 149). As the then Home Secretary, Michael Howard, argued at the 1995 Conservative Party Conference, 'it's time to get honesty back into sentencing. Time to back the courts. And time to send a powerful message to the criminal. No more automatic release. No more release regardless of behaviour. And no more half- time sentences for full time crimes' (cited in Windlesham 2001: 3). Since that time this populist refrain has become a recurring theme within public discourse, disrupting the operation of a bifurcated system and, somewhat ironically, promoting reforms which make it more, rather than less likely, that the executive will be forced to take steps to modify the sentence of the courts in the medium to long-term. 


\section{Conclusion}

These pressures are unlikely to recede in the short-term. During the recent Conservative Party leadership contest the front-runner, and now serving Prime Minister, Boris Johnson signalled his intent to reform the parole system in his regular column for the Daily Telegraph newspaper to His critique of 'early release' drew heavily upon the familiar tropes of penal populism; a determination to side with the 'law abiding majority'; a suspicion of unaccountable liberal elites, an othering of violent offenders and an aversion to early release mechanisms said to undermine 'truth in sentencing',

What is going on with these parole boards? One has the impression that they are simple slaves to political correctness, and unaccountable for the risks they take with public safety. It is becoming more and more regular for prisoners to be let out early - even when they have been convicted of the most serious and violent crimes. We need a two-pronged approach... (The Telegraph, 28 May 2019)

Since Johnson assumed office in July 2019, the Ministry of Justice has announced a further review of the parole system and a series of measures intended to restrict the availability of parole for offenders sentenced to immediate custody for violent or sexual offences (The Times, 1 October 2019). At a time of considerable uncertainty in British politics it is unclear whether these plans will ever be fully realised, however, it is surely noteworthy that a 'two-pronged approach' continues to do much of the rhetorical heavy lifting in the passage above. The idea that prison release should function as both a bridge and a barrier between prison and the community is now firmly entrenched within British penal policy and this 'policy tradition' presents policy-makers with powerful institutional incentives to continue working within these developmental pathways (see Beckett et al 2018). In some cases, the lifecycle of new penal policy ideas can be fleeting and short-lived, but the bifurcation of prisoner release demonstrates what can happen when this process has advanced to a stage where institutional gains are increasingly marginal but, 
diminishing returns do not yet justify radical departures. In this context, prisoner release has become defined by inertia and policy drift with very significant implications for the legitimacy, effectiveness and administrative coherence of the current prisoner release framework.

\section{Notes}

${ }^{1}$ Andrew Ashworth has gone so far as to speak of a 'trifurcated' sentencing framework encompassing the treatment of (i) minor offenders, (ii) those found guilty of serious offences and (iii) those deemed to present a significant risk of harm to the public (2010: 421).

${ }^{2}$ In May 2019, the Justice Secretary announced a new 'blueprint' for probation services in England and Wales. Under the new operating model all offender management responsibilities including the post-release supervision of short-sentence offenders - will transfer to the National Probation Service (NPS). Each NPS region will commission a private or voluntary sector 'innovation partner' to help deliver a range of 'rehabilitation services' (MOJ 2019d).

\section{References}

Annison, H. (2015) Dangerous Politics: Risk, Political Vulnerability and Penal Policy. Oxford: Oxford University Press.

Ashworth, A. (2010) Sentencing and Criminal Justice 5th Edn. Cambridge: Cambridge University Press.

Beland, D. and Cox, R.H. (2010) Introduction: Ideas and Politics. In D. Béland and R.H. Cox (eds) Ideas and Politics in Social Science Research. Oxford: Oxford University Press 
Beckett, K. et al. (2018) US Criminal Justice Policy and Practice in the Twenty-First Century: Toward the End of Mass Incarceration? Law \& Policy, 40(4): 321-345.

Bottoms, A.E. (1977) 'Reflections on the Renaissance of Dangerousness' Howard Journal of Criminal Justice, 16: 70-96.

. (1980) Introduction to The Coming Crisis in A.E. Bottoms, and R.H. Preston, (eds) The Coming Penal Crisis: A Criminological and Theological Exploration. Edinburgh: Scottish Academic Press.

Brown, M. (1996) Serious Offending and the Management of Public Risk in New Zealand. British Journal of Criminology, 36(1): 18-36

Brown, M., and Pratt, J. (eds) (2000) Dangerous offenders: Punishment and Social Order. London: Routledge.

Burke, L and Collett, S. (2016) 'Transforming Rehabilitation: Organizational Bifurcation and the End of Probation as We Knew It?' Probation Journal, 63(2): 120-135.

Cavadino, M, Dignan, J, and Mair, G. (2013) The Penal System: An Introduction 5th Edn. London: Sage.

Downes, D and Morgan, R. (2012) 'Overtaking on the Left? The Politics of Law and Order in the "Big Society"' in M. Maguire, R. Morgan, and R. Reiner, (eds) The Oxford Handbook of Criminology 5th Edn. Oxford: Oxford University Press. 
Feeley, M and Simon, J. (1992) 'The New Penology: Notes on the Emerging Strategy of Corrections and its Implications'. Criminology, 30(4): 449-474.

Garland, D. (1996) 'The Limits of the Sovereign State: Strategies of Crime Control in Contemporary Society' British Journal of Criminology, 36(4): 445-471.

Guiney, T. (2018) Getting Out: Early Release in England and Wales, 1960-1995. Oxford: Oxford University Press.

Hall, P.A. (1989) Conclusion: The Politics of Keynesian Ideas, in P.A. Hall, (ed). The Political Power of Economic Ideas: Keynesianism Across Nations. Princeton, N.J: Princeton University Press.

Heclo, H. (1974) Modern Social Politics in Britain and Sweden. New Haven: Yale University Press.

HM Inspectorate of Prisons (2016) Unintended consequences: Finding a way forward for prisoners serving sentences of imprisonment for public protection. London: HMSO.

Home Office. (1959) Penal Practice in a Changing Society: Aspects of Future Development (England and Wales). Cmnd 645. London: HMSO.

Kemshall, H. (2003) Understanding Risk in Criminal Justice. London: Open University Press. 
. (2013) Dangerous Offenders: Release and Resettlement in A. Hucklesby and 1. HagleyDickinson (eds). Prisoner resettlement: Policy and practice, Cullompton: Willan.

Kerr, P. (2001) Postwar British Politics: From Conflict to Consensus. London: Routledge.

Matthews, R. (1979), Decarceration and the fiscal crisis, in R. Fine et al (eds) Capitalism and the Rule of Law: From Deviancy Theory to Marxism. London: Hutchinson

Mehta, J. (2010) The Varied Roles of Ideas in Politics: From 'Whether' to 'How'. In D. Béland and R.H. Cox (eds) Ideas and Politics in Social Science Research. Oxford: Oxford University Press, p: 23-46.

Ministry of Justice. (2018) Review of the law, policy and procedure relating to Parole Board decisions. Cm 9611. London: HMSO

. (2019a) Press release: Justice Secretary David Gauke sets out long-term for justice, 18 February 2019. Website: https://www.gov.uk/government/news/justice-secretary-david-gauke$\underline{\text { sets-out-long-term-for-justice }}$

. (2019b) Home Detention Curfew (HDC) Policy Framework. Website: https://www.gov.uk/government/publications/home-detention-curfew . (2019c) Offender Management statistics quarterly: October to December 2018. Table 1.1. 
. (2019d) Press release: Justice Secretary announces new model for probation. Website:

https://www.gov.uk/government/news/justice-secretary-announces-new-model-for-probation

Osborne, Booth and Reilly v. The Parole Board. [2013] UKSC. 61.

Padfield, N. (ed) (2007) Who to Release? Parole, Fairness and Criminal Justice. Devon: Willan Publishing.

. (2010) Justifying indefinite detention - on what grounds? Criminal Law Review, 11: 797-822.

. (2016) 'Editorial: A New Chapter for the Parole Board'. Criminal Law Review, 6: 379-380

Padfield, N, Smit, DZ, and Dunkel, F. (2010) Release from Prison: European Policy and Practice. $2^{\text {nd }}$ Edn. Abingdon: Routledge.

Pitts, J. (1988) The Politics of Juvenile Crime. London: Sage.

Pratt, J. (1995) 'Dangerousness, Risk and Technologies of Power ', Australian and New Zealand Journal of Criminology, 28:1-30

. (2007) Penal Populism. London: Routledge.

R v Brooke [2008] EWCA Civ 29.

R (DSD \& Anor) v The Parole Board of England and Wales [2018] EWHC 694 (Admin) 
Robinson, G. (2008) Late-modern rehabilitation: The evolution of a penal strategy. Punishment \& Society 10(4): 429-445.

Seeds, C. (2017) Bifurcation nation: American penal policy in late mass incarceration. Punishment \& Society, 19(5): 590-610.

Shute, S. (2003) 'The Development of Parole and the Role of Research in its Reform' in L. Zedner, and A. Ashworth (eds) The Criminological Foundations of Penal Policy: Essays in Honour of Roger Hood. Oxford: Oxford University Press.

. (2004) Does parole work? The empirical evidence from England and Wales. Ohio State Journal of Criminal Law, 2(1): 315-331.

The Telegraph (2019) Boris Johnson: Letting drug dealers out of prison to go on spa breaks is criminally stupid. The Telegraph, 9 May 2019. Website:

https://www.telegraph.co.uk/politics/2019/05/19/letting-drug-dealers-prison-go-spa-breakscriminally-stupid/

The Times (2019) More prison time for rapists and killers. The Times, 1 October 2019. Website: https://www.thetimes.co.uk/article/more-prison-time-for-rapists-and-killers-bvjhm8khl Windlesham, L. (2001) Responses to Crime, Volume 4: Dispensing Justice. Oxford: Clarendon Press. 
Table 1: Sentenced prison population by offence group, 2002-2014

\begin{tabular}{|c|c|c|c|c|c|}
\hline \multirow{2}{*}{ (2) } & 30-June-02 & 30-June-06 & 30-June-10 & 30-June-14 & \multirow[t]{2}{*}{$\%$ change $2002-14$} \\
\hline & $\%$ & $\%$ & $\%$ & $\%$ & \\
\hline Sexual offences & 5,294 & 6,598 & 9,304 & 11,192 & $+111 \%$ \\
\hline Violence against the person & 12,212 & 16,215 & 20,247 & 19,596 & $+60 \%$ \\
\hline Robbery & 7,522 & 8,415 & 8,834 & 8,507 & $+13 \%$ \\
\hline Drug offences & 10,067 & 10,647 & 11,064 & 10,306 & $+2 \%$ \\
\hline Theft and handling & 4,739 & 4,125 & 3,850 & 4,377 & $-8 \%$ \\
\hline Burglary & 9,156 & 7,791 & 6,857 & 7,141 & $-22 \%$ \\
\hline Other & 8,282 & 9,613 & 10,715 & 10,242 & $+24 \%$ \\
\hline Sentenced Population & $\begin{array}{ll}57,272 & 100\end{array}$ & $63,404 \quad 100$ & $\mathbf{7 0 , 8 7 1}$ & 71,361 & $+25 \%$ \\
\hline
\end{tabular}

Table 2: Sentenced prison population by type of custody, 2005-2018

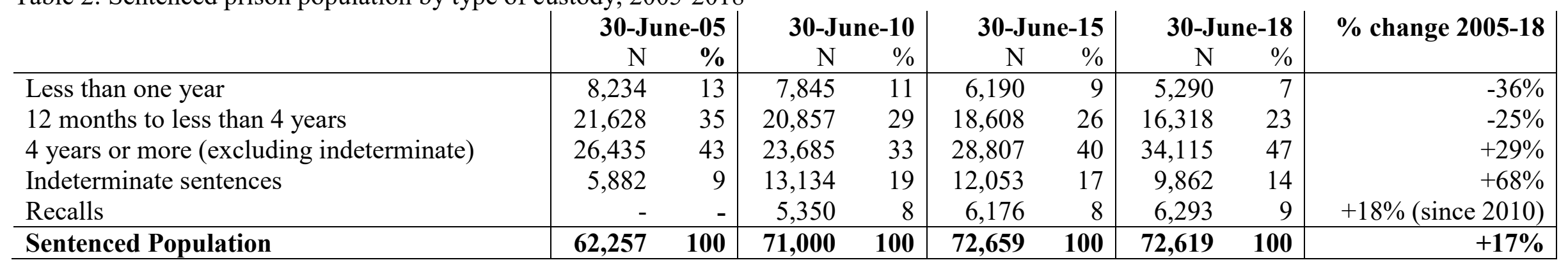

Table 3: Mean time served in prison (months), 2005-2018

\begin{tabular}{|c|c|c|c|c|c|}
\hline & 2005 & 2010 & 2015 & 2018 & $\%$ change $2005-18$ \\
\hline Less than or equal to 6 months & 3.4 & 3.2 & 3.2 & 3.1 & $-9 \%$ \\
\hline Greater than 6 months to less than 12 months & 8.7 & 8.6 & 8.5 & 8.4 & $-3 \%$ \\
\hline 12 months to less than 4 years & 24.1 & 23.7 & 24.4 & 25.3 & $+5 \%$ \\
\hline 4 years or more (excluding indeterminate) & 70.5 & 71.7 & 75.2 & 78.9 & $+12 \%$ \\
\hline Mandatory lifers & 168 & 192 & 192 & 204 & $+21 \%$ \\
\hline Other lifers & 72 & 132 & 168 & 204 & $+183 \%$ \\
\hline Sentence lengths (determinate sentences) & 15.4 & 17.7 & 18.4 & 20.4 & $+32 \%$ \\
\hline
\end{tabular}

Source: MOJ. (2019) Offender management statistics quarterly: October to December 2018. Tables A3.1 and A3.2i. 